\title{
VIP Regimen
}

National Cancer Institute

\section{Source}

National Cancer Institute. VIP Regimen. NCI Thesaurus. Code C63794.

A regimen consisting of etoposide, ifosfamide and cisplatin used for the treatment of advanced-stage germ cell gonadal cancers. 